Konrad Szocik

Wyższa Szkoła Informatyki i Zarządzania w Rzeszowie

\title{
MARIANA MORAWSKIEGO KONCEPCJA WYCHOWANIA DO ŻYCIA W PAŃSTWIE
}

[Education for life in the state within Marian Morawski's philosophy of education]

S u m m a ry: Marian Morawski pessimistically evaluated the development seen within the second half of the 19th century. He criticized socialism and liberalism, idealism and materialism. He drew attention to the cult of technology and hard work. He predicted that this kind of civilization would lead to war. Philosophy was responsible for this dangerous turn because of its rejection of realism and common sense. Education for life in the state requires a realistic philosophy, which develops morality and a critical approach to reality.

Keyw ord s : philosophy, religion, socialism, liberalism, materialism

\section{Wprowadzenie}

Myśl pedagogiczną, społeczną oraz polityczną neotomistów charakteryzuje ścisły związek między zasadami i koncepcjami metafizycznymi oraz epistemologicznymi a postulowanymi rozwiązaniami praktycznymi. Zagadnienie neotomistycznej filozofii państwa i społeczeństwa oraz odniesienia jednostki do życia politycznego i społecznego można przedstawić przynajmniej dwojako. Jedno z podejść zakłada odniesienie do podstaw metafizycznych i epistemologicznych, które kształtują pewną wizję świata i konsekwentnie uzasadniają, a w pewnym sensie „zmuszają” do wyprowadzenia określonych konkluzji. Przykładem takim może być metafizyczne napięcie między pojęciami wolności i tolerancji religijnej, które opierają się na odmiennych zasadach metafizycznych. Wizja świata, rozumienie człowieka i religii funkcjonujące $\mathrm{w}$ ramach koncepcji tolerancji religijnej w Kościele rzymskokatolickim uległo zmianie po zaakceptowaniu na Soborze Watykańskim II koncepcji wolności religijnej. Zmiana ta wymagała zastąpienia, przynajmniej $\mathrm{w}$ tym kontekście, filozofii neotomistycznej 
koncepcjami idealistycznymi i personalistycznymi ${ }^{1}$. Drugie podejście koncentruje się na praktycznych oraz szczegółowych aplikacjach filozofii politycznej, społecznej oraz etyki neotomistycznej i nie musi explicite odwoływać się do podstaw metafizycznych. W niniejszym tekście uwzględniam oba podejścia.

Neotomizm jest filozofią realistyczną. Jako realizm sprzeciwia się założeniom idealizmu, który kwestionuje zdolności poznawcze człowieka i sugeruje pewnego rodzaju agnostycyzm teoriopoznawczy ${ }^{2}$. Neotomizm uznaje zatem, mimo radykalnej idealistycznej krytyki realizmu trwającej przynajmniej od czasów filozofii Immanuela Kanta, możliwość poznania świata i uzyskania prawdziwej wiedzy. Wiedza ta może być tylko jedna, nie może bowiem współistnieć wiele różnych prawdziwych obrazów rzeczywistości. Tylko jeden z nich może być prawdziwy, pozostałe będą jedynie nieuzasadnionymi bądź błędnie uzasadnionymi fikcjami. To założenie metafizyczne realizmu determinuje wnioski o charakterze społecznym i politycznym. Jego konsekwencją jest przekonanie, że również w tym jednym w sposób pewny poznawanym świecie muszą istnieć lepsze i gorsze rozwiązania praktyczne, z których jedne szkodzą człowiekowi, a inne mu służą.

Jednym z najwybitniejszych polskich myślicieli neotomistycznych byl Marian Morawski. Jego Wieczory nad Lemanem przetłumaczono na dziesięć języków obcych, samych tylko wydań niemieckojęzycznych do $1938 \mathrm{roku}^{3}$ ukazało się piętnaście. Morawski szczególnej krytyce poddawał idealizm transcendentalny właściwy filozofom niemieckim. Jego odniesienie do idealizmu charakteryzowało podkreślanie praktycznych konsekwencji wyrastających z przyjętych zasad filozoficznych. Wobec idealizmu niemieckojęzycznego zajmował stanowisko, że filozofia ta ma szczególnie niebezpieczny potencjał, który jest groźny zarówno w sensie globalnym, jak i przede wszystkim dla Polski.

\section{Prymat moralności kształtowanej przez religię nad etyką}

Jednym z istotnych elementów głoszonej przez Morawskiego koncepcji państwa i społeczeństwa była krytyka socjalizmu. Zdaniem filozofa ustanowienie socjalistycznej formy rządów o charakterze antyreligijnym doprowadziłoby do autodestrukcji społeczeństwa oraz uniemożliwiło

\footnotetext{
${ }^{1}$ Por. K. Szocik, L'Idea della tolleranza nella dottrina della Chiesa Cattolica: un breve schizzo Orbis Idearum. History of Ideas NetMag, vol. 1, Issue 2 (2014), s. 85-95.

${ }^{2}$ K. Szocik, Neotomistyczna krytyka idealizmu w polskiej filozofii przełomu XIX i XX wieku, w: M. Karas (red.), Historia filozofii - meandry kultury. Teksty $i$ studia ofiarowane Jackowi Widomskiemu z okazji 65. urodzin, Kraków 2014, s. 233-234.

${ }^{3}$ Od Wydawnictwa, w: M. Morawski, Wieczory nad Lemanem, Warszawa 1984, s. 5.
} 
funkcjonowanie społeczeństwa i państwa. Wynika to z podstawowej roli odgrywanej przez moralność, która odnosi się do sumienia, a także reguluje wszystkie poziomy relacji międzyludzkich. Moralność rozumiem jako zgodność sądów z sumieniem, która hipotetycznie powinna być właściwością całego gatunku ludzkiego. Takie rozumienie moralności znajduje swoje uzasadnienie $\mathrm{w}$ podejściu intuicjonistycznym, wspieranym przez badania psychologiczne i biologiczne. Podeście to uznaje istnienie pewnych intuicji i emocji moralnych, które są pierwotne i niezależne od ewolucyjnie późniejszego poziomu moralności, poziomu osądu i rozumowania ${ }^{4}$.

Domeną państwa jest etyka, ale nie moralność. W przypadku socjalizmu etyka odnoszona do idei sprawiedliwości i instytucji kary miałaby gwarantować przestrzeganie porządku. Etyka oznacza określoną treść, arbitralny i konwencjonalny zestaw norm, który służy uporządkowaniu danego fragmentu czasu i przestrzeni. Etyka może zgadzać się z moralnością, ale może również z nią kolidować. Etyka nie jest w stanie zdyscyplinować ludzi, ponieważ wymagane jest określone kształtowanie i oddziaływanie na jednostkowe sumienie (czyli moralność), co stanowi domenę wyłącznie religii ${ }^{5}$.

Podejście to można interpretować bądź jako podkreślające nieodzowność religii dla moralności, bądź jako instrumentalne, polityczne wykorzystanie religii. Stanowisko Morawskiego było zgodne z opinią Leona XIII, który w encyklice Libertas. O wolności człowieka $\mathrm{z} 1888$ roku krytykował socjalistyczny postulat rozdziału Kościoła i państwa: „Stąd wyłania się owa zgubna maksyma o rozdziale spraw państwa i Kościoła. Nietrudno jednak zrozumieć, jak niedorzeczna to mowa. I nie niedorzecznie powiedziano, że ta zgoda podobną jest połączeniu, jakie między duszą a ciałem, i to z korzyścią dla obydwu części, zachodzi: ich rozerwanie zgubnym jest przede wszystkim dla ciała, bo przygasza jego życie"6.

Cztery lata wcześniej ten sam papież przestrzegał przez oddziaływaniem masonerii, którą oskarżał o powiązanie $\mathrm{z}$ ruchem socjalistycznym. W encyklice Humanum genus. O masonerii z 1884 roku krytykował koncepcję rozdziału Kościoła ze względu na niszczenie prawdziwej moralności przez koncepcję moralności „świeckiej”, „wolnej” czy „niezależnej”: „Toteż jedyną moralnością, która znalazła uznanie u adeptów sekty masońskiej i według której chcieliby wychowywać młodzież, to moralność zwana przez nich «moralnością świecką», «niezależną» lub

${ }^{4}$ J. Haidt, The Emotional Dog and Its Rational Tail: A Social Intuitionist Approach to Moral Judgment, Psychological Review, 2001, Vol. 108, No. 4, s. 814; F. de Waal, Wieża moralności, w: tegoż, Matpy i filozofowie. Skąd pochodzi moralność?, tłum. B. Brożek, M. Furman, Kraków 2013, S. 199-202.

${ }_{6}^{5}$ M. Morawski, Wieczory nad Lemanem, s. 12 i n.

${ }^{6}$ Leon XIII, Libertas. O wolności czlowieka (20 VI 1888 r.), Warszawa 2001, s. 21 i n. 
«wolną», inaczej mówiąc moralność, w której nie ma miejsca dla jakiejkolwiek idei religijnej. Jak bardzo taka moralność jest niewystarczająca, do jakiego stopnia brak jej wewnętrznej siły, jak łatwo się chwieje pod naporem namiętności, można się wystarczająco przekonać widząc już opłakane jej skutki. Albowiem tam, gdzie zająwszy miejsce moralności chrześcijańskiej zaczęła swobodniej panować, tam szybko można było dostrzec zanik uczciwości i upadek obyczajów, umacnianie się najbardziej wynaturzonych poglądów i powszechny zalew zuchwałej przestępczości. Wszystko to wywołuje skargi i powszechne ubolewanie, budząc niejednokrotnie oddźwięk nawet $\mathrm{u}$ tych, którzy wbrew sobie muszą uznać oczywistość tej prawdy."

Niezależnie od nadrzędnej wartości poprawnie ukształtowanego sumienia Morawski przypominał, że na gruncie prawodawstwa publicznego, które musi odwoływać się do elementów intersubiektywnych, istotną rolę odgrywa właściwe rozumienie zasad etycznych, szczególnie w przypadku tworzenia prawa i możliwości przynajmniej częściowej partycypacji w tym procesie różnych grup społecznych ${ }^{8}$. Jeżeli osiągniecie stanu, w którym wszystkie jednostki posiadać będą odpowiednio ukształtowane sumienie (moralność), jest niemożliwe bądź mało prawdopodobne, praktycznym rozwiązaniem pozostaje właściwe opracowanie etyki. Konieczność odniesienia do religii $\mathrm{w}$ procesie legislacyjnym nie wynika tylko $\mathrm{z}$ jej pozytywnego oddziaływania na moralność, ale przede wszystkim z natury człowieka. Człowiek jest animal religiosum, dlatego rugowanie religii ze społeczeństwa i państwa jest sprzeczne z naturalnym, w pewnym sensie biologicznym oraz psychologicznym stanem i prowadzi do sytuacji patologicznych ${ }^{9}$. Morawski podkreśla zgodność religii z rozumem, krytykuje też interpretowanie jej jako fenomenu irracjonalnego powiązanego z emocjonalnością ${ }^{10}$.

\section{Rola filozofii w wychowaniu i krytyka materializmu}

Filozofia jest drugim, obok religii, podstawowym remedium na problemy współczesnego świata. Odpowiednie ukształtowanie struktur państwowych, przede wszystkim prawodawstwa publicznego, wymaga odpowiedniego wychowania jednostki do życia w państwie. Rolę szczególną w wychowaniu odgrywa filozofia. W pewnym sensie ważniejsza jest nawet od religii. Filozofia, a nie nauka, określa ramy poglądu na świat i decyduje, w jaki sposób przebiegać będzie interpretacja i wyjaśnianie poszczególnych zjawisk i faktów.

\footnotetext{
${ }^{7}$ Leon XIII, Humanum genus. O masonerii (20.04.1884), http://www.nonpossumus.pl/encykliki/Leon_XIII/humanum_genus/hg.php (dostęp: 10.10.2014).

${ }^{8}$ M. Morawski, Filozofia i jej zadanie, Kraków 1899, s. 365.

${ }^{9}$ M. Morawski, Wieczory nad Lemanem, s. 22.

${ }^{10}$ Tamże, s. 26 i n.
} 
Niezależnie od stopnia rozwoju nauki można utrzymać religijny obraz świata, który nie koliduje z wyjaśnieniem naukowym, to ostatnie bowiem nie ingeruje $\mathrm{w}$ zagadnienia metafizyczne.

Morawski podkreśla, że materialistyczna wizja świata jest koncepcją filozoficzną, a nie teorią naukową i to materializm wstępnie przyjęty jako teoria rzeczywistości prowadzi do redukcjonistycznego, ograniczonego postrzegania świata. Przyjęta na wstępie koncepcja filozoficzna warunkuje sposób odczytywania wyników badań naukowych, ponieważ nauka sama nie implikuje materializmu ani ateizmu. Filozofia rozstrzyga o akceptacji bądź odrzuceniu religii. Jeżeli religia nie koliduje z nauką, ale może być wykluczana przez pewne koncepcje filozoficzne, czynnikiem rozstrzygającym przestaje być nauka, a staje się nim kryterium doboru właściwej filozofii.

Morawski wskazuje, że prawdziwa filozofia ma uznawać jedność piękna, prawdy i dobra oraz głosić realizm moralny ${ }^{11}$. Ens, verum et bonum convertuntur ${ }^{12}$. Schyłek XIX wieku to okres upadku filozofii, która ustąpiła miejsca historii filozofii, a w ocenie świata nauki i opinii publicznej stała się czymś nieużytecznym i niepotrzebnym. Morawski za jedną z przyczyn tego upadku uznaje samą filozofię, która szczególnie za sprawą idealizmu niemieckiego utraciła zdroworozsądkowy charakter ${ }^{13}$. Filozofia rozwinęła się w złym kierunku, jej idealistyczny zwrot doprowadził do materializmu, mimo że - jak zauważa Morawski - wartość idealizmu transcendentalnego polegała na tym, że „ową upadlającą doktrynę do czasu przynajmniej stłumiła"14 (tą „upadlającą" doktryną jest materializm). Panteizm oznacza ateizm, a koncepcja moralna wskazująca na autonomię człowieka zniosła jedyne kryterium moralności - odniesienie do Boga. W ten sposób filozofia, zamiast służyć, zaczęła szkodzić społeczeństwu i państwu, a w potocznym odbiorze $\mathrm{w}$ Polsce utożsamiano ją z ateizmem ${ }^{15}$.

Materializm powiązany z idealizmem nie tylko zniekształcił filozofię. Zaszkodził także kulturze i cywilizacji. Morawski ocenia sceptycznie ich rozwój, ukazując iluzoryczność postępu. Cywilizacja mnoży potrzeby, zwiększa pragnienia i żądze, przez co rodzi niepokój ${ }^{16}$. Jedyną prawdziwą cywilizacją jest chrześcijaństwo, którego znamieniem jest potencjał moralny i eksponowanie miłości między ludźmi ${ }^{17}$; ale tylko chrześcijaństwo

\footnotetext{
${ }^{11}$ Tamże, s. 44-46.

${ }^{12}$ M. Morawski, Filozofia i jej zadanie, s. 327.

${ }^{13}$ Tamże, s. VII-IX.

${ }^{14}$ Tamże, s. 73.

${ }^{15}$ Tamże, s. XIV i n.

${ }^{16}$ M. Morawski, Wieczory nad Lemanem, s. 52.

${ }^{17}$ Tamże, s. 85 i n.
} 
rzymskokatolickie. Protestantyzm nie jest prawowitym dziedzictwem nauczania Jezusa, znosi zasadę autorytetu i jednej władzy, przez co ulega sekularyzacji i względności nauczania ${ }^{18}$.

Materializm wyrastający $\mathrm{z}$ nieprawidłowo rozumianej filozofii i zniekształcający rozwój cywilizacji staje się, obok socjalizmu, największym zagrożeniem dla społeczeństwa i państwa. Jednym z zadań filozofii zdrowego rozsądku jest demaskowanie bezpodstawności materializmu. Inne zagrożenia niesie bezrefleksyjne stosowanie słów takich jak „oświata, humanitarność, wolność, narodowość”, które szczególnie za sprawą prasy zyskują globalne oddziaływanie na opinię publiczną i, odpowiednio wykorzystane bądź zmanipulowane, mogą ksztaltować postawy społeczne ${ }^{19}$. W tym kontekście warto przypomnieć stanowisko Leona XIII, który w encyklice Libertas skrytykował postulat wolności pisania i myślenia jako niezgodny z prawem naturalnym, nakazującym respektowanie prawdy: „Z tego zatem, co się powiedziało, wynika, że żadną miarą nie wolno żądać, bronić, użyczać wolności myślenia, pisania, nauczania, również i wolności wyznawania jakich bądź religii, jakby tyluż praw, nadanych człowiekowi z natury. Gdyby je bowiem prawdziwie natura dała, uwłaczanie panowaniu Boga byłoby prawem, a żadna ustawa nie mogłaby umiarkować wolności ludzkiej."${ }^{20}$

Także tutaj, w praktycznym dla państwa kontekście wolności mówienia i pisania, Morawski dostrzegał kluczową rolę odgrywaną przez filozofię, której zadaniem ma być świadome i odpowiedzialne koordynowanie oraz kontrolowanie olbrzymiej ilości informacji: „Niezawodnie wiemy wiele rzeczy, których dawniej nie wiedziano; czytamy i piszemy bez porównania więcej, niż dawniej czytano i pisano; ale z tem wszystkiem mniej umiemy myśleć, mniej zdajemy sobie sprawę z tego, co w nas wmawiają lub co sami twierdzimy. Przyczyna tego usterku leży po części w tem samem, że tak wiele i tak prędko czytamy i piszemy. Ale właśnie też dlatego potrzeba nam dziś więcej, niż kiedykolwiek zdrowej i gruntownej filozofii, któraby była tłem i podstawą naszych zdań i wiadomości, która by nauczyła naszych myślicieli myśleć ściśle i zwięźle, iść do gruntu rzeczy, sprowadzać zdania potoczne do zasad niezachwianych, uchraniać się lapek sofistycznych wywodów - któraby wreszcie dała nam pewny pogląd na cały nasz duchowy widnokrąg i skupiłaby naszą wiedzę w jednolitą całość”"1.

Jeżeli istnieje jedna prawda, którą można poznać, a takie jest przecież podstawowe założenie realizmu, to wolność słowa i prasy uzasadniałaby

\footnotetext{
${ }^{18}$ Tamże, s. 132-135.

${ }^{19}$ M. Morawski, Filozofia i jej zadanie, s. XVIII i n.

${ }^{20}$ Leon XIII, Libertas. O wolności człowieka, s. 36.

${ }^{21}$ M. Morawski, Filozofia i jej zadanie, s. XIX.
} 
propagowanie tego, co jest fałszem (kłamstwem) i sankcjonowałaby zachowania niemoralne kolidujące $\mathrm{z}$ wiedzą o tej jednej prawdzie.

Produktem ubocznym materializmu, negatywnym skutkiem pozytywnego procesu rozwoju nauki i techniki, jest prymat kształcenia zawodowego, które jest korzystne i niezbędne dla wypracowania oraz uzyskania stosownych umiejętności praktycznych w danej specjalizacji, ale nie odnosi się do tych wyższych, a zarazem najważniejszych elementów człowieka i prowadzi do „karłowatości duchowej” ${ }^{22}$. Braki filozoficzne dostrzegalne są nawet $\mathrm{w}$ pracach naukowych, które naznaczone są terminologiczną i pojęciową nieprecyzyjnością, niejasnością i niekonkluzywnością wniosków, myleniem tezy z hipotezą, a uzasadnionego twierdzenia z przypuszczeniem ${ }^{23}$. Tak fundamentalna społecznie rola filozofii sprawia, że jej wyraźne sprecyzowanie było istotne szczególnie dla Polski schyłku XIX wieku, kiedy powstawały różne ośrodki naukowe i dydaktyczne, jak również liczne prace istotne także pod względem kształtowania poglądów na świat ${ }^{24}$.

\section{Ostrzeżenie przed zgubnym wpływem materializmu na rozwój cywilizacji}

Intensywna ekspansja rozwoju naukowego i technicznego implikuje inne niebezpieczeństwa. Morawski, odnosząc się do budowy Wieży Eiffela w Paryżu, przestrzegał przed bezkrytyczną wiarą i zaufaniem w potęgę nauki. Przywołał Ucznia czarnoksiężnika Johanna Wolfganga Goethego, w którym bohater pod nieobecność swojego mistrza rozkazuje demonowi przynieść wodę, ale nieomal tonie, ponieważ nie zna zaklęcia odczarowującego wcześniejsze polecenie ${ }^{25}$. Ilustruje to stopniowe podporządkowywanie człowieka pracy, której warunki i standardy wyznacza rozwój nauki i techniki.

Podporządkowanie człowieka pracy niszczy więzi rodzinne, pozbawia wolnego czasu, narusza obrzędowość religijną poprzez obowiązek pracy w niedziele i święta, a przede wszystkim wykorzystuje i niszczy tak fizycznie, jak i psychicznie: „Duch natury wcielił się na zaklęcie człowieka w maszynę, przybrał sto ramion stalowych, któremi poruszają wszystkie siły przyrody, ażeby wyręczać człowieka $\mathrm{w}$ pracy. Ale niebawem, zamiast mu pomagać, maszyna $\mathrm{w}$ tej nierównej spółce zmusza człowieka, żeby on się do niej stosował, zaprzęga go do pracy cięższej niż przedtem; ona nim włada, ona go tyranizuje. Maszyna nie zna rodziny - i ludzie muszą łamać domowe

${ }^{22}$ Tamże, s. XX.

23 Tamże, s. XXI.

${ }^{24}$ Tamże, s. XXII.

25 M. Morawski, Podstawy etyki i prawa, Kraków 1930, s. 250. Por. J.W. Goethe, Der Zauberlehring, http://meister.igl.uni-freiburg.de/gedichte/goe_jwo7.html (dostęp: 12.10.2014). 
warsztaty, przy których wśród rodziny na chleb zarabiali, muszą porzucać żony i dzieci, dla usługi maszyny. Maszyna nie zna Boga - i ludzie muszą o Bogu zapominać, muszą dzień Pański i nabożeństwo i słowo boże i boży spoczynek poświęcać dla obsługi maszyny. Maszyna ma żelazne muskuły, spoczynku nie potrzebuje - i ludzie muszą dniem i nocą przy niej nieprzerwanie pracować, muszą wytężać swe siły nad miarę, ukrócać życie, by dotrzymać kroku żelaznemu olbrzymowi. I nie przestając na tem, maszyna i kobiety i dzieci groźbą głodu ściąga, i te wątłe istoty między swe koła i szyny sprzęga. Słowem, maszyna w tej spółce pracy z człowiekiem, będąc mocniejszą, gniecie człowieka w swem żelaznem objęciu, i jego samego w maszynę przerabia." ${ }^{26}$

Morawski dostrzegał we współczesnych warunkach pracy ryzyko alienacji człowieka, pozbawianie go jego praw, godności i wolności. Zauważył, że w tym niewłaściwym systemie wynagrodzenie ma służyć jedynie utrzymaniu człowieka przy życiu, aby dalej mógł pracować i czyni go niewolnikiem najniższych popędów. Masowa, „maszynowa” produkcja zgubnie wpływa na społeczeństwo, produkuje tanie towary słabej jakości, które należy ciągle zastępować nowymi, kreuje sztuczne, nieautentyczne potrzeby, ku realizacji których zwracają się nawet najubożsi, bezsensownie wydając tak ciężko zarobione pieniądze ${ }^{27}$. Korzyści odnosi jedynie niewielka grupa posiadających kapitał właścicieli.

W tym upatruje Morawski ogromne zagrożenie niesione przez kapitalizm, który doprowadził do niezwykle szybkiej koncentracji kapitału właścicieli, ale nie zagwarantował proporcjonalnego ogólnego dobrobytu w skali globalnej. Kapitalizm formalnie zastąpił feudalizm, ale w praktyce życia społecznego i stosunków pracy wprowadził jeszcze cięższy system feudalny i jeszcze gorszą pańszczyznę oraz poddaństwo. Wielka Rewolucja zniosła przywileje władców feudalnych, ale nowe przywileje kapitalizmu mają znacznie większy zakres i gwarantują niemal absolutne panowanie już nie nad człowiekiem, ale „siłą produkcyjną, której nie wyzyskać do ostateczności, byłoby uchybić przeciw sobie samemu" 28 . Ten skumulowany kapitał sprawuje faktyczną władzę nie tylko nad społeczeństwem, ale i nad państwem, wywołuje lęk i uzależnia, a w przypadku niekorzystnego stosunku władzy do kapitalistów może zostać przeniesiony w każde inne dowolne miejsce na świecie ${ }^{29}$.

Rozwój nauki i techniki to także ułatwienie zadania zastraszania nie tylko społeczeństw, ale i panujących przez terrorystów. Morawski miał na uwadze nihilistów i anarchistów, przede wszystkim w Rosji, Niemczech czy

\footnotetext{
${ }^{26}$ M. Morawski, Podstawy etyki i prawa, s. 250 i n.

${ }^{27}$ Tamże, s. 252-254.

${ }^{28}$ Tamże, s. 255-256.

${ }^{29}$ Tamże, s. 257.
} 
Wielkiej Brytanii. Już w 1891 roku zdawał sobie sprawę z tego, że przyszłość tylko zintensyfikuje te zjawiska ${ }^{30}$. W tym kontekście przestrzegał przez niebezpieczeństwami stałego militaryzmu, który olbrzymią część dorobku narodowego, rozwoju cywilizacyjnego i naukowego podporządkowuje zbrojeniom, a na gruncie politycznym i społecznym rodzi poczucie lęku, ale i agresji między narodami i państwami.

Zdaniem Morawskiego odpowiedzialność za ustanowienie tego permanentnego a szkodliwego społecznie militaryzmu ponosi Rewolucja 1789 roku, która w miejsce porządku boskiego ustanowiła porządek siły niemożliwy już do zniesienia. Pogorszeniu uległy relacje między państwami, które nawet jeżeli nie prowadzą wojen, odgradzają się od innych za pomocą polityki celnej i rywalizacji ekonomicznej. Morawski przewiduje nadejście rządów absolutnych opartych na potędze militarnej, które doprowadzą do zniszczenia jednostki i rodziny. Uważa, że jest to nieunikniona konsekwencja absolutyzacji władzy centralnej, współcześnie szczególnie niebezpieczna ze względu na potęgę militarną gwarantowaną przez rozwój nauki ${ }^{31}$.

\section{Ostrzeżenie przed zgubnym wpływem błędnej filozofii}

Zarysowana przez Morawskiego diagnoza współczesnej cywilizacji jest negatywna, a kreślone przez niego perspektywy wskazują na jeszcze bardziej pesymistyczną przyszłość. Jak wspomniałem na wstępie, założenia metafizyczne i epistemologiczne determinują charakter wniosków, również tych posiadających implikacje praktyczne. Morawski dostrzega źródła tych niewłaściwych, wręcz zagrażających istnieniu człowieka kierunków rozwoju w błędnych koncepcjach filozoficznych.

Tym samym Morawski przypisuje filozofii ważne znaczenie praktyczne. Filozofia może udoskonalać człowieka i społeczeństwo, ale nieodpowiednia - może zniszczyć zarówno człowieka, jak i całe społeczeństwa. Filozofia uczy prawdy i wyjaśnia zasady kierujące rzeczywistością. Morawski przypomina o jej jedności i koherentności, której praktyczny walor nie jest dodatkową jej funkcją, ale nieuniknioną konsekwencją założeń teoretycznych ${ }^{32}$. Dlatego tak istotne jest poprawne rozumienie filozofii, która niewłaściwie pojmowana ma szkodliwe implikacje moralne.

Morawski negatywnie ocenia koncepcję moralności rozwijaną przez Immanuela Kanta i Johanna Gottlieba Fichtego, która przedstawia człowieka jako cel aktywności moralnej. Zdaniem Morawskiego podejście to dopuszcza

\footnotetext{
${ }^{30}$ Tamże, s. 258-259.

${ }^{31}$ Tamże, s. 259-264.

${ }^{32}$ M. Morawski, Filozofia i jej zadanie, s. 10 i n.
} 
każdą zbrodnię, o ile posłuży ona do spełnienia egoistycznych dążeń jednostki ${ }^{33}$. Polityczną konsekwencją filozofii moralnej transcendentalizmu jest uzasadnienie polityki Bismarcka. Fichte usankcjonował wszelkie przewroty i rewolucje stwierdzając, że jedynym Bogiem jest porządek moralny świata $^{34}$. Ale najszkodliwszą społecznie i politycznie filozofią miała być filozofia Hegla. Hegel postrzegał państwo jako absolutny i nadrzędny wobec jednostek byt, jako źródło prawa i moralności, wobec którego jednostka ma charakter jedynie przypadkowy i wtórny ${ }^{35}$. Morawski wskazywał, że mimo praktycznie realizowanego $\mathrm{w}$ państwie niemieckim niebezpiecznego potencjału filozofii Heglowskiej wynikającego z zasady absolutyzowania państwa, jej najbardziej niebezpieczną implikacją jest socjalizm: „Jakoż Bismarkowskie państwo, lubo wyzyskało teorye Hegla i filozofii transcendentalnej, jednak nie wyczerpnęło ich jeszcze do dna. W istocie na ich dnie leży widmo socyalizmu, t. j. zagrabienie na rzecz bożka - państwa wszelkich praw indywidualności i rodziny, małżeństwa, wychowania, własności, sumienia i wiary - oto miła konkluzya tej filozofii - latwa do wyprowadzenia." 36

W odniesieniu do Heglowskiej filozofii państwa Morawski zwraca uwagę na praktycznie realizowane absolutystyczne konsekwencje Heglowskiej maksymy Der Staat ist der wirkliche Gott (Filozofia prawa) ${ }^{37}$. Dostrzega konsekwencję w niemieckiej filozofii, kiedy krytycznie analizuje Der Rückgang des Deutschtums Eduarda von Hartmanna postulującego germanizację innych narodów. Morawski widzi ideową kompatybilność między absolutyzacją jaźni, ducha, szczególnie - państwa w koncepcjach Fichtego, Hegla czy Hartmanna a koncepcją absolutystycznej i agresywnej polityki niemieckiej ${ }^{38}$.

W przypadku materializmu Morawski przestrzega przed zgubnymi konsekwencjami zniesienia pojęcia wolnej woli i broni jednostkowej wolności, która stale towarzyszy świadomości przed, w trakcie i po wykonaniu danej czynności. Dlatego deterministyczna teza materializmu negująca wolność woli jest sprzeczna z rzeczywistością i doświadczeniem: „Więc kto zaprzecza wolność, ten albo wcale nie zastanawia się nad sobą, albo sam sobie kłamie, bo wewnętrzna świadomość tej wolności jest tak pewną, tak oczywistą, że człowiek nie może, nawet gwałtem, siebie samego w tej mierze oszukać,

\footnotetext{
${ }^{33}$ Tamże, s. 133 .

${ }^{34}$ Tamże, s. 135.

${ }^{35}$ Tamże, s. 136 i n.

${ }^{36}$ Tamże, s. 138.

${ }^{37}$ M. Morawski, Podstawy etyki i prawa, s. 271-273.

${ }^{38}$ Tamże, s. 273-276.
} 
a nawet gdy mówi, że nie jest wolnym, wie on doskonale, że może tak nie mówić, a gdy to pisze, wie niewątpliwie, że może w każdej chwili pióro porzucić." 39

Naturalną konsekwencją determinizmu jest zniesienie pojęcia odpowiedzialności, a w prawnej praktyce państwa systemu nagrody i kary. Pozostają jedynie „lekarze-maszyniści”, którzy „powinni wszystkiem rządzić i wszelkiemu złemu w ludzkości lekami i sekcyami zaradzać" ${ }^{40}$. Polityczne i społeczne konsekwencje materializmu są gorsze od konsekwencji idealizmu. Idealizm, mimo antropologicznego, a nie teologicznego rozumienia moralności, może zakładać poczucie godności człowieka. Materializm pozbawia człowieka różnicy jakościowej wobec zwierząt, idealizm zachowuje ją dzięki koncepcji imperatywu kategorycznego, „maszkary sumienia”41. Morawski podkreśla, że konsekwentnie przemyślany materializm prowadzi do postaw immoralnych, a przejawy zachowań moralnych u materialistów wynikają z ich, często nieuświadomionego, odniesienia do dziedzictwa chrześcijańskiego ${ }^{42}$.

W kontekście problematyki moralnej i etycznej na poziomie państwowym Morawski ostrzega również przez liberalizmem. Liberalizm został skrytykowany przez Leona XIII w encyklice Immortale Dei między innymi ze względu na odrzucenie koncepcji suwerenności władzy: „Stąd wynika, że władza publiczna jako taka, jest jedynie od Boga. Bóg jeden albowiem jest prawdziwym i najwyższym wszechrzeczy Panem, któremu wszystko co istnieje podlegać musi, a przeto ci, którzy jakąkolwiek posiadają władzę, nie skądinąd, tylko od Boga najwyższego Władcy ją mają." ${ }^{33}$

Morawski wyjaśnia przyczyny tego negatywnego stosunku Kościoła do liberalizmu. Wskazuje, że liberalizm zagraża jednostce, społeczeństwu i państwu, ponieważ znosi kryteria oraz granice moralne i polityczne, a Kościół, sprzeciwiając się mu, ma na uwadze dobro człowieka oraz ochronę jego autentycznej wolności: „Liberalizm, który Kościół potępia - zrozummy to raz na zawsze - nie zależy na tej wolności, do której z przyrodzenia tęskni serce ludzkie; nie jest on wcale zwolnieniem jarzma ludzkiego nad ludźmi - bo do tego zwolnienia nikt tyle co Kościół się nie przyczynił - ale jest tylko zdjęciem wędzidła prawa Bożego, ideą państwa bez Boga, emancypacją społeczności ludzkiej względem Stwórcy i zakonu przyrodzonego - a przez to samo

\footnotetext{
${ }^{39}$ M. Morawski, Filozofia i jej zadanie, s. 198 i n.

${ }^{40}$ Tamże, s. 199.

${ }^{41}$ Tamże, s. 229.

${ }^{42}$ Tamże, s. 230.

${ }^{43}$ Leon XIII, Immortale Dei. O państwie chrześcijańskim (1.11.1885), Warszawa 2001, s. 7.
} 
oddaniem społeczności, bez granic i zastrzeżeń, kaprysowi ludzi, którzy nią zawładną"4.

Boskie pochodzenie władzy państwowej jest elementem prawa naturalnego, ale jej ustrój i forma zależą od uwarunkowań ludzkich. Mimo to sprawujący władzę ponosi moralną odpowiedzialność przez Bogiem i poddanymi. Odwołanie się do „racji stanu” jako elementu usprawiedliwiającego jest niedopuszczalne. Podobnie poddani mają obowiązek posłuszeństwa władzy między innymi ze względu na jej boskie pochodzenie $^{45}$. Morawski wskazuje na konieczność zachowania wyznaniowego charakteru państwa, które - podobnie jak jednostki - musi oddawać cześć Bogu. Państwo, mimo ukierunkowania na inne niż religia cele i zadania, nie może przeszkadzać czy utrudniać dążenia do osiągnięcia celu religijnego, dlatego jego wyznaniowy charakter byłby kompatybilny $\mathrm{z}$ religijnymi dążeniami obywateli ${ }^{46}$. Jedyną prawdziwą religią jest katolicyzm, wszystkie inne są fałszywe, dlatego zasada cujus regio, ejus religio nie może zostać zaakceptowana. Podejście to zakłada teoretyczną, ideową nietolerancję innych wyznań, ale dopuszcza ich tolerancję praktyczną ${ }^{47}$. Prawna relacja między państwem a Kościołem powinna polegać na ich współpracy, wspólnym sprawowaniu rządów nad poddanymi, a nie być regulowana przez konkordat, który jest jedynie formą rozwiązania sytuacji spornych ${ }^{48}$.

\section{Zakończenie}

Morawski dostrzegał u schyłku XIX wieku szereg zagrożeń, których przyczyną był niewłaściwy rozwój filozofii oderwanej od zdroworozsądkowych zasad (idealizm) i nieuwzględniającej innych niż materialne i zmysłowe elementów rzeczywistości (materializm). W pewnym sensie Morawski opowiadał się za zainicjowaniem pracy u podstaw na gruncie pedagogicznym. Podkreślał, że wychowanie jednostki do życia w państwie powinno rozpoczynać się od wychowywania dzieci. Przede wszystkim wymagana jest edukacja elementarna obejmująca naukę czytania i pisania, rachunki oraz podstawowe zagadnienia dotyczące praw przyrody i ustroju państwa. Mimo naturalnego prawa rodziców do decydowania o wychowaniu i edukacji dzieci, państwo musi zagwarantować minimum edukacyjne adekwatne do poziomu rozwoju

\footnotetext{
${ }^{44}$ M. Morawski, Podstawy etyki i prawa, s. 210 i n.

${ }^{45}$ Tamże, s. 213-215.

${ }^{46}$ Tamże, s. 216.

${ }^{47}$ Tamże, s. 217, 220 i n.

${ }^{48}$ Tamże, s. 227-229.
} 
cywilizacyjnego. Każde dodatkowe przedsięwzięcie edukacyjne zależałoby jednak od decyzji rodziców ${ }^{49}$.

Morawski podkreślał wagę tworzenia katolickich szkół wyznaniowych, szczególnie na poziomie szkolnictwa ludowego. Uważał, że szkoły wyznaniowo mieszane będą sprzyjać rozwojowi relatywizmu i indyferentyzmu, ponieważ na tym etapie rozwoju dziecko nie wypracuje tolerancji wobec odmienności, ale odmienność ta doprowadzi je do obojętności ${ }^{50}$. Morawski zaproponował koherentną, $\mathrm{w}$ pewnym sensie globalną, wizję wychowania do życia w państwie, która swoje podstawy znajdowała we właściwym rozumieniu filozofii i integralnym spojrzeniu na człowieka.

Streszczenie: Marian Morawski pesymistycznie oceniał tendencje rozwojowe drugiej połowy XIX wieku. Krytykował socjalizm i liberalizm. Ostrzegał przed idealizmem i materializmem. Wskazywał na kult techniki i ciężkiej pracy. Przewidywał, że taka cywilizacja musi doprowadzić do wojny. Zdaniem Morawskiego odpowiedzialność za ten niewłaściwy rozwój ponosi filozofia, która odrzuciła realizm i zdrowy rozsądek. Wychowanie do życia w państwie wymaga właśnie filozofii realistycznej, która umożliwi ukształtowanie moralności i krytyczny stosunek do rzeczywistości.

Słowa kluczowe: filozofia, religia, socjalizm, liberalizm, materializm

\footnotetext{
${ }^{49}$ Tamże, s. 337.

${ }^{50}$ Tamże, s. 344 i n.
} 